\title{
Report on Abstracts of the 15th Meeting of IIM, the Interuniversity Institute of Myology - Assisi (Italy), October 11-14, 2018
}

\author{
Davide Gabellini (1), Antonio Musarò (2)
}

(1) Gene Expression and Muscular Dystrophy Unit, Division of Genetics and Cell Biology, IRCCS San Raffaele Scientific Institute, Milano, Italy; (2) DAHFMO-Unit of Histology and Medical Embryology, Laboratory Affiliated to Istituto Pasteur Italia - Fondazione Cenci Bolognetti, Sapienza University of Rome, Rome, Italy

This article is distributed under the terms of the Creative Commons Attribution Noncommercial License (CC BY-NC 4.0) which permits any noncommercial use, distribution, and reproduction in any medium, provided the original author(s) and source are credited.

\begin{abstract}
On October 11-14, 2018, the 15th Meeting of the Interuniversity Institute of Myology (IIM) took place in the city Assisi, Italy. Muscle researchers from Italy, and various European and North-American countries gathered to discuss recent results on the physiology and diseases of skeletal muscle. The program showcased keynote lectures from world-renowned international speakers presenting advances in muscle stem cells, circadian rhythm, organismal development and growth, muscle physiology, and bioengineering. Novel, unpublished results from young trainees were presented as oral communications or posters, based on selection from submitted abstracts. Young trainees where directly involved in several aspects of the meeting by being responsible of organizing a scientific session, arranging three round tables tailored to the interests of their peers and chairing all scientific sessions. The meeting offered a unique opportunity for young researchers to present their work, have feedback from more experienced colleagues and establish collaborations to further understanding of muscular diseases and develop therapeutic strategies. The open, informal and friendly atmosphere of the meeting stimulated lively discussions, instrumental to highlight key areas of muscle research and foster scientific cross-fertilization and new collaborations. The meeting was very successful. A sign that the IIM community will continue to deliver important contributions to the training of young students and fellows, promoting our understanding of muscle formation and activity, the mechanism of muscle diseases and the progress toward therapeutic approaches. The Myology field is strong and articulated in basic, translational and early clinical research, moving toward the development of treatments for several muscle diseases as documented by the abstracts of the IIM meeting.
\end{abstract}

Key Words: Human denervated muscle; SCI; Elderly, Recovery of external-work contractility; Home Based Functional Electrical Stimulation, Myokines, IGF-1.

Eur J Transl Myol 28 (4): 401-403, 2018

The Interuniversity Institute of Myology (IMM) was founded in 2003 with the purpose of supporting the training of young researchers and foster the collaboration of investigators involved in muscle research in Universities and Research Centers in Italy and abroad. Young trainees are at the core of IIM mission, as well as the promotion of interdisciplinary and collaborative research to advance the understanding of muscle development, the regulation of its activity, its repair upon injury and how alteration of these processes bring about pathological conditions. The ultimate goal is to stimulate researchers, clinicians and patient associations to collaborate for accelerating progress toward the development of treatments for neuromuscular diseases. The 15th IIM Meeting took place in Assisi, Italy form October 12 to 15, 2018. Researchers, clinicians, and representative of patients and pharma organizations from Italy met with international colleagues to discuss recent results in the muscle field. The meeting was opened by a Special Lecture by Giorgio Fanò, one of the IIM founders and the first director of IIM, which gave an historic perspective of muscle research to celebrate IIM 15th birthday. There were four Keynote Lectures. Shahragim Tajbakhsh (Institut Pasteur-France) described recent results concerning the extrinsic and intrinsic regulation 
of muscle stem cell activity during homeostasis and regeneration. Paolo Sassone-Corsi (University of California Irvine-USA) presented findings revealing the molecular connections between epigenetics, metabolic pathways and the circadian clock. Carmine Settembre (TIGEM-Italy) illustrated how the developmental regulation of lysosome biogenesis shapes cellular identity and function. Nenad Bursac (Duke UniversityUSA) summarized recent developments in the engineering of three-dimensional human skeletal muscle tissues as platform for the development of novel therapeutics for muscle disorders. Based on the submitted abstracts, thirty seven contributions were selected for Oral Communications that were grouped in seven Sessions chaired by young trainees: 1 . Signaling in muscle growth, homeostasis and disease; 2. Satellite cells and muscle regeneration in healthy muscle and in diseases; 3. Synaptic transmission and E-C coupling in healthy and diseased muscle; 4 . Genetic and epigenetic alterations in muscle dystrophies and myopathies; 5. Metabolic alterations and muscle diseases; 6. Muscle fibrosis, sarcopenia and cachexia; 7. Therapeutic approaches for muscle diseases. Forty Poster presentations, always on display during the entire Meeting, completed the Program. Talks and Posters generated lively and exciting scientific discussions, which were continued through spontaneous gatherings of several groups at coffee breaks and after lunch and dinner leading to the development of new collaborations. Together with the Italian, the international participation is increasing every year, a strong indication that this community of myologists is able to attract scientists with a wide range of expertise. The meeting has been very successful and instrumental to promote the engagement of experienced researchers and junior scientists for the identification of emerging areas of research aimed at understanding the causative mechanisms of muscle diseases and develop more efficient therapeutic strategies. On the first evening of the meeting, young trainees organized Roundtable Discussions during which students and fellows discussed about issues and new ideas in an informal way, over food and drinks provided by local producers. The roundtables were organized on Muscle regeneration and tissue engineering (moderated by Nenad Bursac and Shahragim Tajbakhsh); Metabolism, exercise and signaling pathways in muscle wasting (moderated by Maria Pennuto and Paolo Sassone-Corsi); Muscular dystrophies (moderated by Davide Gabellini and Graziella Messina). On the second evening of the meeting, guided tours were organized to Spello (one of the most beautiful villages in Italy) including a visit to Cappella Baglioni (famous for Pinturicchio's frescoes) (https://en.wikipedia.org/wiki/ Baglioni_Chapel), the "Infiorate" museum (http://www. infiorataspello.it) and a nearby Roman villa (https://www.villadeimosaici dispello.it/en), which has been recently restored and displays astonishing mosaics. The evening concluded with a "ancient roman" style show and dinner in the wonderful rooms of Spello town hall. Finally, an Award Cerimony was held on the last evening of the meeting to congratulate Marianna Cosentino, Ersilia Fornetti, Enrico Pozzo and Valentina Taglietti winners of prices for best Oral and Poster presentations selected by an international panel composed by the Invited Speakers and members of the IIM Scientific Committee.

Since 2010, the collections of abstracts presented to the annual IIM Meeting were published in the European Journal of Translational Myology, an Open Source Journal whose broad contents are retrievable in PUBMED from 2014 and more recently in SCOPUS and the eWeb of Science. The collections of abstracts of IIM Meetings provide information on research lines on basic and translational myology. More clinically oriented myology results, related to muscle repair and rehabilitation, were also published in the collections of abstracts of the PaduaMuscleDays, a series of International Meetings that were held in Euganei Hills and Padua, Italy. All together, these collections of abstracts show that results from basic, translational and clinical myology are maturing toward the common goals of improving the quality of life and finding a cure for neuromuscular patients. ${ }^{1-17}$ It is very likely that the IIM community will continue to deliver important contributions to these themes and attract a broader and interdisciplinary audience.

\section{List of acronyms}

IMM - Interuniversity Institute of Myology

\section{Author's contributions}

Authors equally contributed to write the manuscript.

\section{Funding}

This typescript was sponsored by the A\&C M-C Foundation for Translational Myology, Padova, Italy

\section{Conflict of Interest}

None of the authors have conflicts of interests.

\section{Ethical Publication Statement}

We confirm that we have read the Journal's position on issues involved in ethical publication and affirm that this report is consistent with those guidelines.

\section{Corresponding Authors}

Davide Gabellini, Gene Expression and Muscular Dystrophy Unit, Division of Genetics and Cell Biology, IRCCS San Raffaele Scientific Institute, Milano, Italy. Email: gabellini.davide@ @sr.it

Antonio Musarò, DAHFMO-Unit of Histology and Medical Embryology, Laboratory Affiliated to Istituto Pasteur Italia - Fondazione Cenci Bolognetti, Sapienza University; Center for Life Nano Science@Sapienza, IIT, Rome, Italy.

E-mail: antonio.musaro@uniroma1.it 


\section{References}

1. Renzini A, Benedetti A, Bouchè $\mathrm{M}$, et al. Culture conditions influence satellite cell activation and survival of single myofibers. Eur J Transl Myol. 2018 May 29;28(2):7567. doi: 10.4081/ejtm.2018.7567. eCollection 2018 Apr 24.

2. Pette D, Vrbová G. The Contribution of Neuromuscular Stimulation in Elucidating Muscle Plasticity Revisited. Eur J Transl Myol 2017 Feb 24;27(1):6368. doi: 10.4081/ejtm.2017.6368. eCollection 2017 Feb 24. Review

3. Carraro U. 2017 Spring PaduaMuscleDays, roots and byproducts. Eur J Transl Myol 2017;27:6810. doi: 10.4081/ejtm.2017.6810. eCollection 2017 Jun 24.

4. Pigna E, Greco E, Morozzi G, et al. Denervation does not Induce Muscle Atrophy Through Oxidative Stress. Eur J Transl Myol 2017;27:6406. doi: 10.4081/ejtm.2017.6406. eCollection 2017 Feb 24.

5. Lavorato M, Gupta PK, Hopkins PM, FranziniArmstrong C. Skeletal Muscle Microalterations in Patients Carrying Malignant Hyperthermia-Related Mutations of the e-c Coupling Machinery. Eur J Transl Myol 2016;26:6105. doi: 10.4081/ejtm. 2016.6105. eCollection 2016 Sep 15

6. Carotenuto F, Coletti D, Di Nardo P, Teodori. L $\alpha$ Linolenic Acid Reduces TNF-Induced Apoptosis in C2C12 Myoblasts by Regulating Expression of Apoptotic Proteins. Eur J Transl Myol 2016;26:6033. doi: 10.4081/ejtm. 2016.6033. eCollection 2016 Sep 15.

7. Mosole S, Carraro U, Kern H, et al. Use it or Lose it: Tonic Activity of Slow Motoneurons Promotes Their Survival and Preferentially Increases Slow Fiber-Type Groupings in Muscles of Old Lifelong Recreational Sportsmen. Eur J Transl Myol 2016;26:5972. doi: 10.4081/ ejtm.2016.5972. eCollection 2016 Sep 1.

8. Hiroux C, Vandoorne T, Koppo et al. Physical Activity Counteracts Tumor Cell Growth in Colon Carcinoma C26-Injected Muscles: An Interim Report. Eur J Transl Myol 2016;26:5958. doi: 10.4081/ejtm.2016.5958. eCollection 2016 Jun 13.

9. Tramonti C, Rossi B, Chisari C. Extensive Functional Evaluations to Monitor Aerobic Training in Becker Muscular Dystrophy: A Case Report. Eur J Transl Myol 2016;26:5873. doi: 10.4081/ejtm.2016.5873. eCollection 2016 Jun 13.
10. Riuzzi F, Beccafico S, Sorci G, Donato R. S100B protein in skeletal muscle regeneration: regulation of myoblast and macrophage functions. Eur J Transl Myol 2016;26:5830. doi: 10.4081/ejtm. 2016.5830. eCollection 2016 Feb 23.

11. Gabrielli E, Fulle S, Fanò-Illic G, Pietrangelo T. Analysis of Training Load and Competition During the PhD Course of a 3000-m Steeplechase Female Master Athlete: An Autobiography. Eur J Transl Myol 2015;25:5184. doi: 10.4081/ejtm.2015.5184. eCollection 2015 Sep 11.

12. Franzini-Armstrong C. Electron Microscopy: From $2 \mathrm{D}$ to 3D Images with Special Reference to Muscle. Eur J Transl Myol 2015;25:4836. doi: 10.4081/ejtm.2015.4836. eCollection 2015 Jan 7. Review.

13. Ravara B, Gobbo V, Carraro U, et al. Functional Electrical Stimulation as a Safe and Effective Treatment for Equine Epaxial Muscle Spasms: Clinical Evaluations and Histochemical Morphometry of Mitochondria in Muscle Biopsies. Eur J Transl Myol 2015;25:4910. doi: 10.4081/ejtm.2015.4910. eCollection 2015 Mar 11.

14. Cvecka J, Tirpakova V, Sedliak M, Kern H, Mayr W, Hamar D. Physical Activity in Elderly. Eur J Transl Myol 2015 Aug 25;25(4):249-52. doi: 10.4081/ejtm.2015.5280. eCollection 2015 Aug 24. Review.

15. Edmunds KJ, Gargiulo P. Imaging Approaches in Functional Assessment of Implantable Myogenic Biomaterials and Engineered Muscle Tissue. Eur J Transl Myol 2015;25(2):4847. doi: 10.4081/ejtm.2015.4847. eCollection 2015 Mar 11. Review.

16. Costa A, Rossi E, Scicchitano BM, Coletti D, Moresi V, Adamo S. Neurohypophyseal Hormones: Novel Actors of Striated Muscle Development and Homeostasis. Eur J Transl Myol 2014;24(3):3790. doi: 10.4081/ejtm.2014.3790. eCollection 2014 Sep 23. Review

17. Veneziani S, Doria C, Falciati L, et al. Return to Competition in a Chronic Low Back Pain Runner: Beyond a Therapeutic Exercise Approach, a Case Report. Eur J Transl Myol 2014;24:2221. doi: 10.4081/ejtm.2014. 2221. eCollection 2014 Sep 23.

Received for publication: 30/11/2018. Accepted for publication: 30/11/2018. 